\title{
Pemberian Pelatihan Analisis Butir Soal Bagi Guru di Kabupaten Jombang; Efektif?
}

\section{Riza Yonisa Kurniawan}

Universitas Negeri Surabaya, Indonesia, rizakurniawan@ unesa.ac.id

\author{
Albrian Fiky Prakoso \\ Universitas Negeri Surabaya, Indonesia, albrianprakoso@unesa.ac.id \\ Luqman Hakim \\ Universitas Negeri Surabaya, Indonesia, luqmanhakim@unesa.ac.id \\ Retno Mustika Dewi \\ Universitas Negeri Surabaya, Indonesia, retnomustika@unesa.ac.id \\ Irin Widayanti \\ Universitas Negeri Surabaya, Indonesia, irinwidayati@unesa.ac.id
}

\begin{abstract}
Teacher's unfamiliarity in analyzing items is one of the factors causing teacher to be reluctant to do item analysis. While the item analysis is needed to establish the problem as an evaluation tool to measure the level of students' understanding of the material being studied. The purpose of this training is to (1) provide teacher understanding about the item analysis (2) to provide assistance in analyzing the items, (3) to provide assistance to teachers in practicing the analysis of items using software anates. The subject of this study is the teacher of Vocational High School in Jombang regency. With object study training analsis item using Anates software. The results of the training were very effective as evidenced by the majority of participants being able to practice the item analysis, but some participants were reluctant to analyze the items due to age and lack of time and effort.
\end{abstract}

Keywords: $\quad$ Analysis of items, Vocational Teachers, Training

\section{PENDAHULUAN}

\section{Analisis Situasi}

Sesuai dengan UU Nomor 14

Tahun 2005 pasal 10 ayat 1 guru merupakan agen pembelajaran yang diharuskan memiliki beberapa kompetensi yaitu ; (1) Kompetensi Available at http://journal.unj.ac.id/unj/index.php/jpm
Pedadogik, (2) Kompetensi Pribadi, (3). Dalam pembelajaran guru berperan sebagai fasilitator dan evaluator. Peran guru sebagai fasilitator adalah merancang dan melaksanakan kegiatan pembelajaran sesuai dengan kebutuhan siswa. 179 
Sebagai evaluator guru diharuskan dapat melakukan penilai terhadap seluruh proses pembelajaran, baik pencapaian kompetensi peserta didik dan kemajuan hasil belajar. Untuk itu guru perlu menyusun perangkat evaluasi yang tepat untuk mengukur capaian kompetensi siswa, dalam hal ini adalah penyusunan butir soal. dapat mengukur secara tepat kompetensi siswa, soal yang telah disusun terlebih dahulu harus diuji kevalidannya.

Kegiatan menganalisis butir soal merupakan suatu kegiatan yang harus dilakukan guru untuk meningkatkan mutu soal yang telah ditulis. Kegiatan ini merupakan proses pengumpulan, peringkasan, dan penggunaan informasi dari jawaban siswa untuk membuat keputusan tentang setiap penilaian (Nitko, 1996: 308). Tujuan penelaahan adalah untuk mengkaji dan menelaah setiap butir soal agar diperoleh soal yang bermutu sebelum soal digunakan. Di samping itu, tujuan analisis butir soal juga untuk membantu meningkatkan tes melalui revisi atau membuang soal yang tidak efektif, serta untuk mengetahui informasi diagnostik pada siswa apakah mereka sudah/belum memahami materi yang telah diajarkan (Aiken, 1994: 63). Soal yang bermutu adalah soal yang dapat memberikan informasi setepattepatnya sesuai dengan tujuannya di antaranya dapat menentukan peserta didik mana yang sudah atau belum menguasai materi yang diajarkan guru.

Dalam melaksanakan analisis butir soal, para penulis soal dapat menganalisis secara kualitatif, dalam kaitan dengan isi dan bentuknya, dan kuantitatif dalam kaitan dengan ciri-ciri statistiknya (Anastasi dan Urbina, 1997: 172) atau prosedur peningkatan secara judgment dan prosedur peningkatan secara empirik (Popham, 1995: 195). Analisis kualitatif mencakup pertimbangan validitas isi dan konstruk, sedangkan analisis kuantitatif mencakup pengukuran kesulitan butir soal dan diskriminasi soal yang termasuk validitas soal dan reliabilitasnya.

Jadi, ada dua cara yang dapat digunakan dalam penelaahan butir soal yaitu penelaahan soal secara kualitatif dan kuantitatif. Kedua teknik ini masing-masing memiliki keunggulan 
dan kelemahan. Oleh karena itu teknik terbaik adalah menggunakan keduanya (penggabungan). Kedua cara ini diuraikan secara rinci dalam buku ini.

\section{Perumusan Masalah}

Berdasarkan studi pendahuluan pada SMA menunjukkan bahwa guru memiliki kesulitan dalam menyusun instrumen. Soal yang disusun kurang dapat mengukur kompetensi siswa, hal ini dikarenakan dalam analisis butir soal masih menggunakan metode manual, sehingga analisis butir soal kurang objektif. Hal inilah yang menjadi dasar diadakannya pelatihan analisis butir soal menggunakan program aplikasi Anates, dengan tujuan untuk meningkatkan kompetensi guru dalam penyusunan butir soal. Namun dalam pengabdian ini ditekankan pada penyusunan instrumen dalam bentuk soal pilihan ganda.

\section{Tujuan dan Manfaat}

Hal ini dilakukan agar guru dapat menyusun soal yang digunakan untuk try out siswa seperti halnya try out UNAS, OSN, UAS, dan evaluasi lainnya dengan kualitas yang sudah layak digunakan.

\section{KAJIAN TEORITIK}

Tujuan utama analisis butir soal dalam sebuah tes yang dibuat guru adalah untuk mengidentifikasi kekurangan-kekurangan dalam tes atau dalam pembelajaran (Anastasi dan Urbina, 1997:184). Berdasarkan tujuan ini, maka kegiatan analisis butir soal memiliki banyak manfaat, di antaranya adalah: (1) dapat membantu para pengguna tes dalam evaluasi atas tes yang digunakan, (2) sangat relevan bagi penyusunan tes informal dan lokal seperti tes yang disiapkan guru untuk siswa di kelas, (3) mendukung penulisan butir soal yang efektif, (4) secara materi dapat memperbaiki tes di kelas, (5) meningkatkan validitas soal dan reliabilitas (Anastasi and Urbina, 1997:172). Di samping itu, manfaat lainnya adalah: menentukan apakah suatu fungsi butir soal sesuai dengan yang diharapkan, (2) memberi masukan kepada siswa tentang kemampuan dan sebagai dasar untuk bahan diskusi di kelas, (3) memberi masukan kepada guru tentang kesulitan siswa, (4) memberi masukan pada aspek tertentu untuk pengembangan kurikulum, 
merevisi materi yang dinilai atau diukur, meningkatkan keterampilan penulisan soal (Nitko, 1996: 308-309).

Linn dan Gronlund (1995: 315) juga menambahkan tentang pelaksanaan kegiatan analisis butir soal yang hiasanya didesain untuk menjawab pert anyaan-pertanyaan berikut ini.(1) Apakah fungsi soal sudah tepat? (2) Apakah soal ini memiliki tingkat kesukaran yang tepat? (3) Apakah soal bebas dari halhal yang tidak relevan? (4) Apakah pilihan jawabannya efektif? Lebih lanjut Linn dan Gronlund (1995: 3 16318) menyatakan bahwa kegunaan analisis butir soal bukan hanya terbatas untuk peningkatkan butir soal, tetapi ada beberapa hal, yaitu bahwa data analisis butir soal bermanfaat sebagai dasar: (1) diskusi kelas efisien tentang hasil tes, (2) untuk kerja remedial, (3) untuk peningkatan secara umum pembelajaran di kelas, dan (3) untuk peningkatan keterampilan pada konstruksi tes.

Berbagai uraian di atas menunjukkan bahwa analisis butir soal adalah: (1) untuk menentukan soal- soal yang cacat atau tidak berfungsi penggunaannya; (2) untuk meningkatkan butir soal melalui tiga komponen analisis yaitu tingkat kesukaran, daya pembeda, dan pengecoh soal, serta meningkatkan pembelajaran melalui ambiguitas soal dan keterampilan tertentu yang menyebabkan peserta didik sulit.

Mutu pendidikan ditentukan pada tahap input adalah bagaimana sumberdaya yang diterima dalam suatu sistem pendidikan antara lain menyangkut bagaimana kualitas input peserta didik, guru, dan sumber daya pendukung lain. Tahap selanjutnya tranformasi yaitu tahap dimana sumber daya yang dimiliki utamanya peserta didik/siswa dikelola dan diproses untuk memiliki kompetensikompetensi yang sesuai dengan targettarget kurikulum. Tahap ketiga adalah tahap output dimana sumber daya utama yaitu peserta didik yang telah melalu proses transformasi dan telah memiliki kompetensi-kompetensi sesuai dengan target kurikulum dan siap digunakan oleh penguna.

Berdasarkan tiga tahapan tersebut yang paling krusial untuk melakukan 
peningkatan mutu pendidikan adalah pada tahap kedua yaitu tahap transformasi. Tahap transformasi ini merupakan suatu tahapan yang merupakan kegiatan utama dalam suatu sistem pendidikan untuk menghasilkan output lulusan yang bermutu.

Kegiatan utama dalam proses tranformasi dalam dunia pendidikan adalah pembelajaran. Oleh karena itu untuk meningkatkan mutu pendidikan tidak akan lepas bagaimana proses pembelajaran berlangsung. Pembelajaran akan berlangsung baik bila semua komponen sumber daya dan perangkat pembelajaran telah dipersiapkan dengan baik. Antara lain strategi pembelajaran, media dan alat evaluasi sebagai komponen perangkat pembelajaran sangat menentukan kualitas pembelajaran.

Disisi lain, salah satu komponen pembelajaran yang dapat menentukan kualitas dan mutu pembelajaran adalah alat evaluasi yang digunakan guru untuk melakukan evaluasi pembelajarannya. Secara teori agar hasil evaluasi yang dilakukan guru itu dapat dipertanggungjawabkan, maka alat evaluasi yang digunakan hasil memenuhi validitas dan reliabilitas yang baik.

Saat ini telah ditemukan software untuk mengetahui tingkat validitas dan reliabilitas alat evaluasi (soal) yaitu software anates yang berfungsi untuk menganalis butir soal, berupa tingkat kesukaran, daya beda, fungsi distraktor, validitas dan reliabilitas soal. Tetapi saat ini guru bila ingin mengetahui tingkat validitas dan reliabilitas soal yang dibuat masih menganalisa dengan secara manual. Pelatihan analisis butir soal harus dilakukan dengan efektif sehingga tujuan pelatihan dapat tercapai dengan maksimal. Hardjana (2001) agar sebuah pelatihan menjadi efektif maka sebelum diadakan harus diadakan analisis kebutuhan pelatihan, kebutuhan pelatihan dapat diperoleh melalui kuisioner, wawancara, dan observasi. Sedangkan menurut Noe (2002) kegiatan pelatihan penting dilakukan untuk meningkatkan pengetahuan, keterampilan atau perilaku yang ditekankan pada program pelatihan dan dapat diaplikasikan dalam kegiatan sehari- 
hari. Wexley (1991) juga menyebutkan tujuan dari pelatihan adalah untuk; (1) meningkatkan selfawarness, (2) meningkatkan keterampilan dan keahlian yang dimiliki, (3) meningkatkan motivasi dan profesionalitas kerja. Sehingga dengan melihat hal tersebut sangat perlu dilakukan workshop software anates sebagai alat analisis butir soal, untuk meningkatkan kemampuan Guru dalam menyusun dan menganalisis butir soal.

\section{MATERI DAN METODE}

\section{Kerangka Pemecahan Masalah}

Kenyataan dilapangan guru tidak selalu melakukan proses validitas dan reliabilitas terhadap soal atau alat evaluasi yang akan digunakan untuk mengevaluasi utamanya alat evaluasi buatan guru (ulangan harian). Alasan yang banyak muncul karena proses validitas dan reliabilitas tersebut membutuhkan waktu yang lama, sulit dan merepotkan.

\section{Realisasi Pemecahan Masalah}

Adapun runtutan kegiatan pelatihan sebagai berikut; 1) Persiapan sosialisasi program, 2) Pendataan guru,
3) Menyusun TIM pelaksana kegiatan pengabdian masyarakat tingkat jurusan, 4) Pengajuan proposal kegiatan masyarakat, 5) Proposal diterima kemudian pelaksanaan. Rendahnya kualitas penyusunan soal di kalangan guru-guru membuat pentingnya dilaksanakan pendampingan pelatihan analisis butir soal.

\section{Khalayak Sasaran}

Kegiatan pelatihan ditujukan untuk guru SMK di Kabupaten Jombang, dengan target peserta \pm 50 orang yang diundang melalui dinas pendidikan dan kebudayaan provinsi jawa timur. Kegiatan pengabdian kepada masyarakat dilakukan dengan cara mengadakan Pelatihan analisis butir soal

\section{Metode}

Berikut metode yang dilakukan :

1. Metode Pelaksanaan

Kegiatan pelatihan analisis butir soal dengan menggunakan anatest dilakukan dengan metode ceramah bervariasi, praktek, diskusi, dan tanya jawab.

2. Materi Pelatihan

Materi yang disajikan pada kegiatan elatihan analisis butir soal dengan menggunakan anatest adalah: 

a. Hakekat analisis butir soal
b. Anatomi analisis butir soal
c. Praktek menganalisis butir soal
d. Tanya jawab

3. Penyusunan soal dengan analisis butir soal oleh peserta

4. Telaah soal yang telah disusun peserta pelatihan

Kegiatan pelatihan ditujukan untuk guru SMK di Kabupaten Jombang, dengan target peserta \pm 50 orang yang diundang melalui dinas pendidikan dan kebudayaan provinsi jawa timur. Kegiatan pengabdian kepada masyarakat dilakukan dengan cara mengadakan Pelatihan analisis butir soal. Adapun runtutan kegiatan pelatihan sebagai berikut; 1) Persiapan sosialisasi program, 2) Pendataan guru, 3) Menyusun TIM pelaksana kegiatan pengabdian masyarakat tingkat jurusan, 4) Pengajuan proposal kegiatan masyarakat, 5) Proposal diterima kemudian pelaksanaan.

Efektifitas kegiatan pelatihan diukur dengan menggunakan kuisioner dan lembar observasi. Variabel yang digunakan untuk mengukur keefektifan pelatihan adalah, kepuasan pada bidang akademik, kesesuaian pemaparan materi oleh Narasumber, dan pengelolaan kegiatan pelatihan. Sedangkan pada lembar observasi yang diukur adalah antusiasme, kemampuan praktek analasis butir soal dengan Anates, dan minat menggunakan analisis butir soal Anates di sekolah setelah mengikuti pelatihan.

$$
\text { Kuisioner yang digunakan }
$$
menggunakan indikator sebagai berikut : Tabel. 2 Indikator Keefektifan Pelatihan

\begin{tabular}{|c|c|}
\hline Akademik & $\begin{array}{l}\text { - Kualitas paparan awal } \\
\text { program } \\
\text { - Kesesuaian materi } \\
\text { dengan tujuan } \\
\text { - Tingkat kemudahan } \\
\text { materi/ handout } \\
\text { - Kualitas urutan } \\
\text { penyajian } \\
\text { - Kecukupan latihan } \\
\text { dalam materi } \\
\text { - Kesempatan dalam } \\
\text { mendapatkan umpan } \\
\text { balik } \\
\text { - Kesempatan } \\
\text { meningkatkan skill }\end{array}$ \\
\hline Narasumber & $\begin{array}{l}\text { - Komponen di bidang } \\
\text { presentasi di forum } \\
\text { ilmiah }\end{array}$ \\
\hline
\end{tabular}




\begin{tabular}{l|l}
\hline & - Efesien dalam \\
menjelaskan konsep & materi \\
- Gaya bahasa yang & komunikatif \\
- Menyenangkan/variatif & dalam menyampaikan \\
& materi \\
- Memberikan cukup & waktu untuk latihan \\
- Memberikan umpan & balik \\
& - Ketepatan waktu \\
\hline Pengelolaan & - Layanan umum panitia \\
- Fasilitas yang diberikan & - Keterjangkauan lokasi \\
\hline
\end{tabular}

Sumber : Data Diolah

\section{HASILDAN PEMBAHASAN}

Hasil

Kegiatan pengabdian kepada masyarakat ini dilaksanakan di SMKN 1 Jombang yang beralamat di Jl. Dr. Soetomo No. 15 Sengon kabupaten Jombang. Kegiatan pengabdian kepada masyarakat ini dilakukan dalam bentuk pelatihan dengan metode ceramah dan praktek menganalisis butir soal sebagai upaya untuk meningkatkan kemampuan

Available at

http://journal.unj.ac.id/unj/index.php/jpm guru di Kabupaten Jombang dalam menyusun soal dengan baik. Kegiatan ini ditujukan kepada guru SMK di kabupaten Jombang sejumlah 52 orang. Sebelum melaksanakan kegiatan pelatihan, dilakukan terlebih dahulu komunikasi dengan perwakilan guru SMK di Jombang. Komunikasi tersebut dilakukan untuk memperoleh jenis materi pelatihan yang dibutuhkan guru disana. Komunikasi tersebut mendapatkan hasil yaitu pelatihan yang dibutuhkan guru antara lain pelatihan elearning, penulisan artikel ilmiah, dan analisis butir soal.

Tim PKM kemudian melakukan koordinasi dengan tim PKM lainnya untuk menyusun perencanaan pelaksanaan PKM. Koordinasi tersebut menghasilkan pembagian materi pada setiap tim PKM sehingga dalam satu tempat, pelatihan diberikan oleh beberapa tim PKM atau dalam arti lain beberapa Tim PKM bergabung menjadi satu pada suatu wilayah pelatihan yaitu di Kabupaten Jombang.

Langkah berikutnya Tim PKM melakukan koordinasi dengan dinas pendidikan provinsi Jawa Timur untuk bekerja sama dalam pelasanaan PKM. 
Dengan demikian peserta diundang oleh dinas pendidikan provinsi jawa timur sehingga tim PKM hanya tinggal mempersiapkan materi pelatihan.

Materi untuk pelatihan analisis butir soal didapatkan dari berbagai dokumen pemateri melalui berbagai kegiatan sebagai reviewer soal evaluasi baik di jenjang SMP maupun SMA dan pelatihan yang diikuti oleh pemateri.

Pelaksanaan pelatihan bertempat di Aula gedung SMKN 1 Jombang. Peserta yang mengikuti pelatihan ini adalah Guru SMK di Kabupaten Jombang yang dipertemukan dalam satu ruang.

Kegiatan pengabdian kepada masyarakat disampaikan kepada guruguru di Kabupaten Jombang dan memperoleh respon positif. Selanjutnya kegiatan dikoordinasikan oleh Tim Pelaksana yaitu dengan cara menyampaikan informasi pelaksanaan Pelatihan analisis butir soal. Pelaksanaan pelatihan dilakukan selama satu hari yaitu pada tanggal 19 Agustus 2017.

Materi yang pertama yaitu Hakekat Analisis Butir Soal disampaikan oleh bapak Dr. Luqman Hakim, M.SA. Materi yang kedua yaitu Anatomi
Analisis Butir Soal yang disampaikan oleh ibu Retno Mustika Dewi, S.Pd., M Pd. Setelah memahami teori, materi dilanjutkan dengan Praktek menganalisis Butir Soal yang dipandu oleh Bapak Riza Yonisa Kurniawan, S.Pd, M.Pd. Pelatihan dilanjutkan dengan sesi Tanya Jawab dan Telaah Analisis Butir Soal yang dipandu oleh semua tim PKM.

Setelah peserta selesai menelaah soal yang telah mereka analisis, maka setiap peserta mengirim hasil telaah tersebut kepada tim PKM dan mempresentasikannya. Kegiatan berikutnya dilanjutkan dengan para pemateri mereview dan memberikan masukan tentang telaah analisis butir soal yang telah dilakukan oleh peserta dan juga dilakukan diskusi antara pemateri dengan peserta.

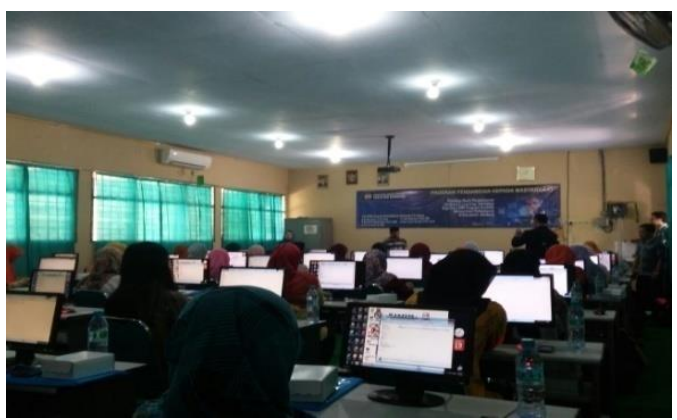

Gambar 1. Kegiatan Pelatihan Sumber: dokumentasi 
Berdasarkan hasil analisis data dari kuisioner yang diberikan kepada sampel yakni Guru SMK di Kabupaten Jombang yang mengikuti kegiatan pelatihan penulisan soal Anates sejumlah 52 orang , diketahui keefektifan pelatihan analsis butir soal dengan menggunakan Anates sebagai berikut.

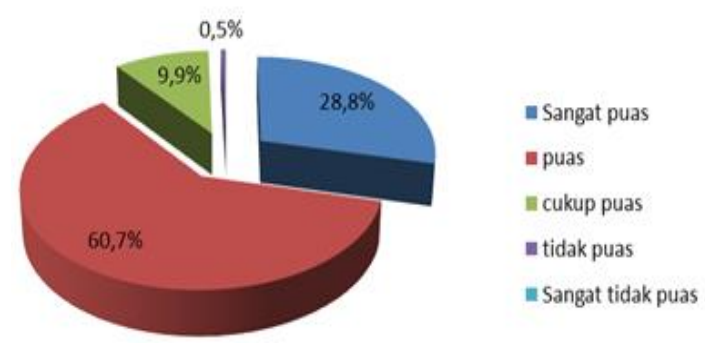

Gambar 2. Diagaram Akademik Sumber: data diolah

Sebanyak $28,8 \%$ peserta merasa sangat puas dan $60,7 \%$ peserta merasa puas dengan aspek akademik yang diberikan oleh tim PKM. Tetapi ada juga peseta yang merasa cukup puas dan tidak puas. Nilai tersebut terletak pada kesempatan meningkatkan skill. Kesempatan ini diarasa diarasa kurang oleh peserta. Hal ini dikarenakan peserta pelatihan terlalu banyak yaitu 52 peserta, sehingga terdapat beberapa peserta yang kurang mendapatkan kesempatan dalam meningkatkan skill.

Available at

http://journal.unj.ac.id/unj/index.php/jpm

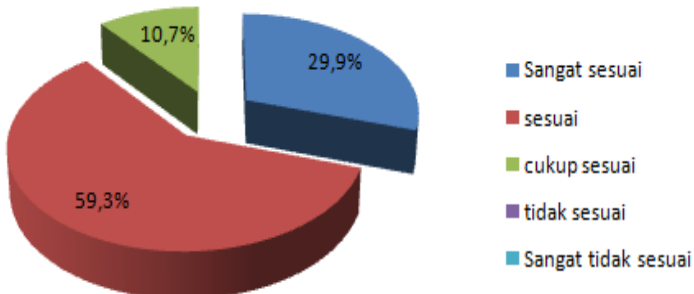

Gambar 3. Diagram Narasumber

Pada dasarnya sebagian besar peserta merasa sangat sesuai dan sesuai tentang narasumber yang menyampaikan materi pada pelatihan ini. Namun disisi lain sebanyak $10,7 \%$ peserta merasa cukup sesuai. Nilai cukup sesuai ini didominasi oleh latihan yang diberikan pemateri dan dirasa kurang oleh peserta. Hal ini dikarenakan pelaksanaan pelatihan terbagi-bagi menjadi beberapa materi dalam satu pelaksanaan PKM, sehingga peserta merasa kurang dalam hal latihan yang diberikan oleh pemateri.

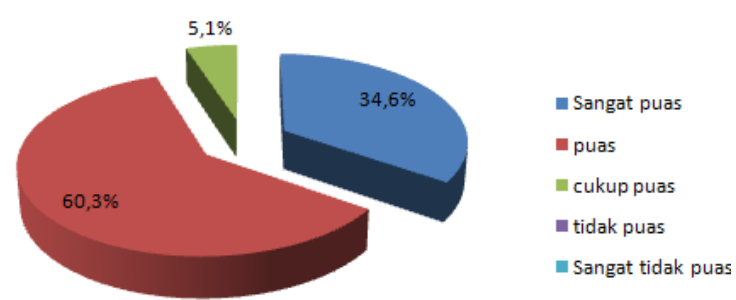

Gambar 4. Diagram Pelaksanaan

Kegiatan

Sumber: data diolah

Aspek pengelolaan/ pelaksanaan sebenarnya tidak hanya Tim PKM yang sepenuhnya berperan, tetapi juga panitia setempat yang menyiapkan tempat dan 
fasilitas dalam pelaksanaan pelatihan. mengakibatkan beberapa peserta Hasil hasil analisis kuesioner yang telah tertinggal ketika mengikuti praktek disebarkan, didapatkan sebagian peserta analisis butir soal. merasa sangat puas dan puas terhadap pengelolaan/ pelaksanaan pelatihan.

Pembahasan

Hanya saja terdapat $5,1 \%$ peserta merasa Luaran dari pelaksanaan PKM ini cukup puas. Hal ini dikarenakan fasilitas yang diberikan seperti halnya ada beberapa komputer yang digunakan peserta mengalami masalah/ error yang

Tabel 1 Hasil Observasi dan Wawancara Pelatihan Analisis Butir Soal

\begin{tabular}{l|l|c|c}
\hline No. & \multicolumn{1}{|c|}{ Aspek } & $\begin{array}{c}\text { Jumlah } \\
\text { Peserta }\end{array}$ & Persentase (\%) \\
\hline 1. & $\begin{array}{l}\text { Antusias dalam mendengarkan } \\
\text { penjelasan materi }\end{array}$ & 52 & 100 \\
\hline 2. & $\begin{array}{l}\text { Mengikuti Pelatihan Analisis Butir } \\
\text { Soal dari awal hingga akhir pelatihan }\end{array}$ & 52 & 100 \\
\hline 3. & $\begin{array}{l}\text { Mampu Mempraktekkan Analisis } \\
\text { Butir Soal sesuai dengan waktu yang } \\
\text { tersedia }\end{array}$ & 49 & 94,2 \\
\hline 4. & $\begin{array}{l}\text { Minat Melakukan analisis butir soal } \\
\text { ketika di sekolah }\end{array}$ & 42 & 80,7 \\
\hline
\end{tabular}

Sumber: Data diolah

Seluruh peserta pelatihan analisis butir soal pada dasarnya antusias dalam mendengarkan penjelasan materi yang diberikan oleh Tim PKM. Disisi lain, semua peserta juga mengikuti keseluruhan rangkaian acara pelatihan dan tidak ada satupun peserta yang meninggalkan tempat pelatihan sebelum acara selesai. Akan tetapi pada saat pelaksanaan mempraktekkan analisis butir soal terdapat peserta yang kurang mampu mengikuti yaitu sebanyak 3 
peserta atau sebanyak 5,8\% dari keseluruhan peserta yaitu 52 peserta. Hal ini dikarenakan komputer yang digunakan peserta mengalami masalah/ error. Akibatnya 3 peserta tersebut ketinggalan proses praktek analisis butir soal. Penyebab berikutnya dikarenakan faktor usia dari peserta. Peserta pelatihan didominasi oleh peserta yang relatif masih muda, sedangkan yang berusia diatas 50 tahunan merasa kesulitan mengikuti pelatihan. Sampai waktu yang teredia habis mereka masih belum mampu mengikuti praktek, namun akhirnya bisa teratasi dengan arahan secara perlahan oleh Tim PKM dan juga Mahasiswa yang tergabung dan membantu Tim PKM, sehingga peserta yang berusia 50 tahun keatas akhirnya dapat terbantu.

Saat tim PKM mewawancarai peserta, terdapat pengakuan yang mengatakan mereka ingin melakukan analisis butir soal ketika mereka membuat soal di sekolah. Namun juga terdapat beberapa peserta yang mengaku tidak mungkin melakukan analisis butir soal. Hal ini didominasi oleh peserta yang berusia lanjut karena kecepatan mereka dalam bekerja sudah menurun.
Sehingga jika mereka melakukan analisis butir soal pada setiap soal yang mereka buat maka waktu yang mereka butuhkan sangatlah banyak dan tidak akan cukup dengan waktu yang tersedia dalam satu semester. Peserta berikutnya sebagian besar adalah peserta perempuan. Peserta perempuan mengatakan bahwa pekerjaan mereka bukan hanya mengajar di sekolah, tetapi juga mengurus anak, membersihkan rumah dan lain sebagainya. Dengan demikian faktor kurangnya waktu dan tenaga yang menyebabkan mereka enggan melakukan analisis butir soal. Sehingga dari hasil analisis observasi dan wawancara dari peserta pelatihan didapatkan kesimpulan bahwa pemberian pelatihan analisis butir soal ini berjalan dengan efektif. Hal ini dibuktikan dengan legih dari 90\% merasa puas dan tingkat pemahaman peserta pelatihan juga lebih dari $80 \%$.

\section{KESIMPULAN DAN SARAN}

\section{Kesimpulan}

Pelaksanaan PKM telah berjalan dengan baik, dari segi pemahaman peserta mampu memahami dengan baik pentingnya analisis butir soal dan pengaplikasian program aplikasi Anates 
untuk menganalisis butir soal. tetapi terdapat peserta yang merasa kurang puas dalam hal kurangnya kesempatan mereka dalam meningkatkan skill, kurangnya waktu yang diberikan narasumber dalam melakukan praktek, dan juga fasilitas seperti komputer yang mengalami ganggguan pada saat pelaksanaan praktek.

Sebagian besar peserta dapat mempraktekkan analisis butir soal dengan komputer dan berminat untuk mengaplikasikan analisis butir soal dengan Anates di sekolah, tetapi terdapat beberapa peserta yang mengalami kesulitan yang dikarenakan faktor usia dan gangguan pada komputer yang mereka gunakan.

Kesimpulan yang terakhir yaitu sebagian besar peserta mampu mempraktekkan analisis butir soal, sehingga kegiatan pelatihan analisis utir soal dengan menggunakan Anates dapat dikatakan efektif. Akan tetapi, beberapa sekolah belum memiliki fasilitas yang memadai untuk menggunakan program aplikasi Anates, sehingga perlu adanya peningkatan sarana dan prasarana.

\section{Saran}

Untuk pelaksanaan PKM berikutnya diharapkan melakukan pengecekan terlebih dahulu terhadap fasilitas yang akan digunakan agar tidak terjadi gangguan pada saat hari pelaksanaan PKM. Dengan adanya peningkatan skill guru dalam melakukan analisis butir soal sebaiknya diimbangi dengan peningkatan fasilitas yang memadai sehingga hasil dari kegiatan pelatihan dapat diaplikasikan secara maksimal di sekolah.

\section{DAFTAR PUSTAKA}

Aiken, L. (1994). Attitudes and related psychosocial constructs: Theories, assessment, and research. Sage.

Anastasi, A., \& Urbina, S. (1997). Psychology testing.

Badan Penelitian dan Pengembangan Pendidikan. 2001. Manajemen Peningkatan Mutu Berbasis Sekolah: Bukul, Konsep dan Pelaksanaan. Jakarta: Departemen Pendidikan Nasional.

Badan Penelitian dan Pengembangan Pendididkan. 2010. Panduan Kebijakan Pemanfaatan Hasil Ujian Nasional Untuk Perbaikan Mutu Pendidikan. Jakarta: Kementerian Pendidikan Nasional.

Crosby, Philip B. 1984. Quality Without Tears: The Art of Hassle- Free Management. New York: Mc. Graw Hill Book Company. 
Hardjana, A. M. (2001). Training Sumber Daya Manusia yang Efektif. Yogyakarta: Kanisius.

Juran, J.M. 1995. Merancang Mutu, Terjemahan oleh Bambang Hartono. Jakarta: PT. Pustaka Binawan Pressindo.

Linn, R. L., \& Gronlund, N. E. (1995). Measuring and assessment in teaching. Miles, M. B. \& Huberman, A. M. 1994. Qualitative data analysis (2nd ed.). Thousand Oaks, CA: Sage.

Noe, R. A. (2002). Employee training and development

Nitko, A. J. (1996). Educational assessment of students. PrenticeHall Order Processing Center, PO Box 11071, Des Moines, IA 50336-1071.

Peraturan Menteri Pendidikan Nasional Republik Indonesia Nomor 22 Tahun 2006 tentang Standar Isi Untuk Satuan pendidikan Dasar dan Menengah. 2006. Jakarta: Puskur.

Peraturan Menteri Pendidikan Nasional Republik Indonesia Nomor 23 Tahun 2006 tentang Standar Kompetensi Lulusan Pendidikan. 2006. Jakarta: Puskur.

Peraturan Menteri Pendidikan Nasional Republik Indonesia Nomor 16 Tahun 2007 tentang Standar Kualifikasi Akademik dan Kompetensi Guru. 2007. Jakarta: Puskur.

Peraturan Menteri Pendidikan Nasional Republik Indonesia Nomor 19 Tahun 2007 tentang Standar Pengelolaan Pendidikan. 2007. Jakarta: Puskur.

Peraturan Menteri Pendidikan Nasional Republik Indonesia Nomor 20
Tahun 2007 tentang Standar Penilaian Pendidikan. 2007. Jakarta: Puskur.

Peraturan Menteri Pendidikan Nasional Republik Indonesia Nomor 41 Tahun 2007 tentang Standar Proses. 2007. Jakarta: Puskur.

Popham, W. J. (1995). Classroom assessment: What teachers need to know. Needham Heights.Sallis, Edward. 1993. Total Quality Management in Education. London: Kogan Page.

Sambasalim. 2011. "Mutu Pendidikan". Diakses dari http://sambasalim.com/pendidika n/mutu-pendidikan.html pada tanggal 11 Mei 2011.

Tampubolon, Daulat P. 1992. Perguruan Tinggi Bermutu: Paradigma Baru Manajemen Pendidikan Tinggi Menghadapi Tantangan Abad Ke-21. Jakarta: Gramedia Pustaka Utama.

Toro, I.J. 1992. Total Quality Management: Three Steps To Continuous Improvement, Reading, MA: Addison-Wesley Publishing Company. h. 31

Umaedi. 11 Mei 2011. "Manajemen Peningkatan Mutu Berbasis Sekolah Sebuah Pendekatan Baru dalam Pengelolaan Sekolah untuk Peningkatan Mutu." (Online) (http://www.ssep.net/director.htm 1. diakses 11 Mei 2011).

Undang-undang Nomor 14 Tahun 2005 Tentang Guru dan Dosen

Wexley, K. N. (1991). Developing and training human resources in organizations (No. C10 25). Harper Collins Publishers. 
Widodo, Duparno Eko. 2011. Manajemen Mutu Pendidikan. Jakarta: PT Ardadizya Jaya.

Yuniarsih,Tjutju. $1997 . \quad$ Kontribusi Kepemimpinan Kepala Sekolah terhadap Manajemen Mutu Sekolah Dasar. Disertasi tidak diterbitkan. Bandung: Program Pascasarjana IKIP Bandung. 